\title{
Transatlantica
}

Revue d'études américaines. American Studies Journal

2 | 2014

Aesthetics of Theory in the Modern Era and Beyond / Photographie documentaire

\section{Daniel Nathan, ed. Rooting for the Home Team, Sport, Community and Identity}

\section{Peter Marquis}

\section{(2) OpenEdition}

\section{Journals}

Electronic version

URL: https://journals.openedition.org/transatlantica/7196

DOI: $10.4000 /$ transatlantica. 7196

ISSN: 1765-2766

\section{Publisher}

Association française d'Etudes Américaines (AFEA)

Electronic reference

Peter Marquis, "Daniel Nathan, ed. Rooting for the Home Team, Sport, Community and Identity",

Transatlantica [Online], 2 | 2014, Online since 20 December 2019, connection on 04 February 2023.

URL: http://journals.openedition.org/transatlantica/7196 ; DOI: https://doi.org/10.4000/transatlantica. 7196

This text was automatically generated on 4 February 2023.

\section{(†)

Creative Commons - Attribution-NonCommercial-NoDerivatives 4.0 International - CC BY-NC-ND 4.0 https://creativecommons.org/licenses/by-nc-nd/4.0/ 


\title{
Daniel Nathan, ed. Rooting for the Home Team, Sport, Community and Identity
}

\author{
Peter Marquis
}

\section{REFERENCES}

NATHAN, Daniel, Rooting for the Home Team, Sport, Community and Identity, Champaign, University of Illinois Press, 2013, 237 pages, ISBN 978-0-252-07914-6, 25 dollars.

1 Rooting for the Home Team, edited by Daniel Nathan, an American Studies professor at Skidmore College, was long overdue when it came out in 2013. The field of sports history had been waiting for a comprehensive volume on the intersections of sport, community, and identity since at least the early 1980s. At the time-the early days of the so-called "new sports history"-the formation of sporting communities received a modicum of academic attention (Rader, 1977; Hardy, 1984; Holt, 1986), only to be eclipsed in the 1990s by studies on gender, race, and ideology in sports. ${ }^{1}$ This may be partly explained by the vagueness of the word "community" and the lack of scholarly consensus as to its meaning and manifestations.

2 As Nathan himself remarks in his introduction, "community is a more complex phenomenon than most of us probably realize" (4). It is undeniable that the word has great emotional heft; it is a "feel-good word" (Procter, 2005) uncritically used on a daily basis in the United States to evoke fondness for a location, neighborly solidarity, or meaningful bonds with like-minded people. In fact, communities come in many stripes, large or small, private or public, ephemeral or long-lasting, actual or virtual, real or imagined, like the oft-cited imagined nation-states (Anderson, 1991). But it would be misguided to look for a finite definition, as community is a social and cultural construct that has no tangible bearings except in the minds of those who feel part of it. "Community is where community happens," Nathan aptly summarizes on page 4, 
quoting historian Thomas Bender, who sees communities as "an experience" rather than a place or a set of shared interests and behavior patterns (Bender, 1982).

Another approach is to construe community as the shared belief in common narratives (such as creation or redemption myths) which bring some people together, while inevitably shutting out others. As feminist scholar Miranda Joseph argues, "to invoke community is immediately to raise questions of belonging and of power" (Joseph, 2002, 7). With its unspoken us-versus-them dichotomy, community is "a discourse that legitimates social hierarchies and may mask power relations that disenfranchise and silence people" (6), notably racial and sexual Others.

In few other sites than sports and sports spectatorship does this approach ring truer. In essence, modern sports is the struggle between two teams or individuals artificially pitted against one another in the interest of a displaced, highly dramatized reenactment of war. Sport is often touted as a level playing field where social hierarchies do not matter, because the rules are the same for everyone and talent is the only discrimination. In fact, it is much more divisive than people readily acknowledge, especially in an era when sport is celebrated for its ability to "sustain social cohesion and foster common understanding" (8). Though outside the scope of this volume, the infamously numerous racial and gender discriminations in US sports (such as baseball pre-Jackie Robinson or track and field pre-Title IX) form the ideological backdrop of most of the essays.

But the main point of focus is what happens off the field, in stadiums, sports bars, in front of TV screens, on street corners, basically anywhere people "talk sports," as the phrase goes. To quote Nathan's introduction, "this book is about the ways different American communities used or use sport to create and maintain a sense of their collective identity. It is predicated on the idea that rooting for the home team often symbolizes a community's preferred understanding of itself, and that doing so is an expression of connectedness" (2). Articulating community and identity (loosely defined as the personal experience of "who we are and what we value" 7), Nathan asserts that "sports are a way that disparate communities define, understand and represent themselves to themselves and to others" (7).

6 To buttress this claim, Nathan uses the fourteen essays that make up this collection. An eclectic mix of history (Michael Oriard, David Wiggins), present-day sociology (Amy Bass), film studies (Carlo Rotella) and even ego-histoire (Susan Cahn, David Zang), the volume covers a wide array of sports (baseball, golf, football, boxing, basketball) practiced at various levels and locales (small-town Iowa, college campuses, big cities, the imagined South, New England, etc.). Most of the contributions converge to claim that "rooting for the home team" forges community and identity, both personal and collective, which is of great import at a time when traditional institutions like church, work, gender or race have been greatly challenged by the new post-industrial order. The 237-page collection includes an introduction, an afterword, the short biography of each author, and an index.

\section{Summary}

7 In the first essay, Mark Dyreson examines sociologists Robert and Helen Lynd's take on sport and community-making in their 1929 classic Middletown. The couple argued that the young boys playing for the local basketball high-school team, "performed civic 
rituals that animated the essential being of the city" (Lynd, 1929, 18). As modernity (automobile, radio) had fundamentally "disenchanted the older communal cosmos" that had bound together the traditional gemeinschaft of Middletown, writes Dyreson, only "basketball magic" remained to "re-enchant the mystic chords of commonweal" (24).

8 Using a large number of primary sources, David Wiggins argues that the Thanksgiving football games between Howard and Lincoln, two historically black universities, brought "additional monies into institutional coffers and provided occasions for fostering school spirit" (45). But they occurred as the Great Migration of southern blacks to the north opened new paths of social mobility and challenged middle-class African-Americans' special status in society, as well as their acceptance by white people. The abundance of social events before and after the games meant to reaffirm the Talented Tenth's higher status "as they distanced themselves from lower-class blacks, whom they blamed for the rising tide of racism" (47).

9 Catherine M. Lewis's piece on Georgia-born golfer Bobby Jones shows that he embodied, and still does to a certain extent, "southern identity and the preservation of privilege." A player from 1916 to 1930, Jones "was lauded for his grace, modesty, sportsmanship and southern charm" (55). He retired early, but "his legacy is still meaningful for contemporary audiences" (57), because he has become "the symbol of Southern prestige, privilege and nostalgia [...], a throwback to an era of southern gentility, [...] a way to hold on to uncomplicated times when everyone-black and white, male and female, rich and poor-ostensibly knew their place" (60). Relying only on secondary sources, the piece sadly takes for granted that "southern identity" exists as given outside of historically and socially located discourses.

10 In his essay on the role of high school football in American communities, Michael Oriard brilliantly makes the case that the "Football Town" narrative created by the sports press in the 1940s and 1950s to evoke an unchanging, idyllic small town-America is in fact complementary to the "Friday Night Lights" narrative. The latter, both in H. G. Bissinger's 1990 novel and Jason Katims's 2006 TV adaptation, casts high school football as the catalyst "for underfunding of education, grotesque pressures heaped on adolescents, and stunted lives of adults." Yet Oriard argues that these narratives should not be construed as polar opposites ("community pride" or "collective pathology"), but both at the same time.

11 The second part of the volume deals with lesser-known sports, such as six-on-six, a peculiar version of basketball played by girls in numerous high school in Iowa in the 1960s and 70s, before rural exodus ushered in the era of school consolidations. Schultz and Lucas demonstrate that this gender-specific version helped small towns "pronounce their civic sense of self through contradistinction," especially during endof-the-year tournaments drawing statewide attention to unknown locations. Despite the adoption of five-player "boys' rules" in the 1980s, six-on-six is still relevant today as online communities tie intergenerational bonds between participants and foster offline communities through reunion games.

Christopher Lamberti sheds light on another local sporting peculiarity, Chicago's sixteen-inch no-glove softball. Very popular in the Windy City's working-class neighborhoods throughout the 20th century, the "Chicago Game strengthened players' and fans' bond to communities they imagined themselves part of" (94). Lamberti insists on the gender dynamics, contending that no-glove softball "helped men retain a 
macho, urban, blue-collar identity in the midst of a changing city" that was replacing manual jobs with clerical ones.

For its third part, Rooting for the Home Team mixes memoir, homage and academic research (sometimes, sadly, less of the latter). Daniel Nathan reminisces about his beloved Baltimore Colts who were "a cherished civic institution endowed with deep, lasting meaning." From the late 1950s until 1984, the Colts breathed life into this declining working class shipyard city. To support his claim that "through the Colts many Baltimoreans 谳....50 constructed a preferred vision of themselves and their community's civic identity," (116) Nathan reveals the significance of the famed 1958 NFL Championship, when the Colts eked out a nail-biter against the Giants. He then deconstructs the semiotics of John Unitas, a player for the Colts from 1956 to 1972 who was "a valued cultural symbol and commodity, something close to a myth, a source of identity and pride" (114).

Can a voice foster community? Absolutely, at least for Elliot Gorn and Allison Lauterbach, who reflect upon their sense of being from Los Angeles because of their attachment to the voice of Vin Scully, for 50 years the radio announcer for the LA Dodgers. Scully's unpretentious tone, soothing cadence, and sheer longevity is said to stand in stark contrast to the City of Angels' taste for glitz, short-lived fame, and constant renewal. Sadly, it is never made clear how and why his peculiar voice is so symbiotic to LA's spirit or identity. But when Gorn argues that "Scully's voicemagically, mysteriously-creates a bond of intimacy and community between himself and the fans," (127), he reinforces the thesis that community is first and foremost a performance whose nature is intangible, yet deeply felt.

David Zang's piece on Penn State's football coach Joe Paterno provides insight into the psychology of those who join sports-based communities. Zang asserts that since no human can be content with being just one person throughout their life, and since "no one wants to live a foolish life," people put on masks, join voluntary associations such as sports-based communities and "defend them to the death" (162). He understands sports-based communities as carnivalesque moments because when people are connected to uniforms, they hold the thought that they are something different. But Zang also forcibly recognizes that so-called "community values" are delusional, as evidenced by Paterno's 2011 downfall when he was fired for failing to take action against sexual abuses occurring in his team's facilities (157).

16 Finally, Susan Cahn's ego-histoire scrutinizes gender in sports-based communities on the backdrop of her life-story as a young athlete, scholar, lesbian, and current member of a Buffalo-based group of amateur basketball players. She feels part of this community because of the common love for playing basketball, respect for different bodies, and off-the-court considerations about each other's ups and downs. Cahn suggests that such communities are valued, because they contradict the premise that the neo-liberal city precludes social bonding.

17 Arguably the most compelling essay in the collection, Amy Bass's "The Anatomy of Red Sox Nation" meets the expectations on this classic subject. Quoting Benedict Anderson, Bass starts off reiterating that community is a mental construct, "a style in which the day-to-day interactions are imagined" (141). For Red Sox fans, this is particularly true as they are scattered throughout New England, the US, and even the world (Lyon, France, has its fair share of devotees). Yet the moniker "Red Sox Nation" is not pure marketing; it is a narrative that binds the community wherever it is located. The 
narrative is sustained by the franchise's history (one of the longest in professional sports), its opposition to New York, and the "curse of the Bambino". ${ }^{2}$ Fenway Park, a cramped, perennially sold-out ballpark in downtown Boston, also contributes to the team's mystique. All in all, people donning the famous red and blue cap with the socks and embroidered "B" are not necessarily dyed-in-the-wool fans, but they tap into the Red Sox narratives of humility, working-class ethos, Irish roots, and manly resilience. This phenomenon happens throughout the world because "Red Sox Nation" has, paradoxically, no frontier. What Bass describes is very close in nature to Lestrelin's study of French supporters who root for the Olympique de Marseille without having set foot in the city of Zidane (Lestrelin, 2010).

\section{Discussion}

Overall, Rooting for the Home Team offers insightful case studies into the vexed question of what sort of communities are formed and valued by sports participants and sports spectators. Yet, the causes and purposes remain largely unexplored. To be fair, postindustrialism is often cited as the prevalent cause, but not only do the authors never define this fraught word, but they also fail to clarify how it contributes to the formation and maintenance of sporting communities. The reader is left to his educated guesses. All in all, sporting communities are uncritically construed as remedies to the allegedly desocializing effects of post-industrialism. The interpretation of sporting communities as mainly compensatory, in fact, feels more convenient than convincing. First, following Coontz (2000), one might question the very notion that there ever were close social bonds in the pre-industrial or industrial ages. Second, as a response to Robert Putnam's famous claim that Americans are now "bowling alone" (Putnam, 1995), an array of critics has retorted that post-industrialization does not obliterate social bonds, but rather re-shapes them (Fowley \& Edwards, 1996; Lemann, 1996). Ironically, a prime example of these newfound social bonds birthed by the information age is provided by the article on 6-on-6 basketball (87-90).

Regarding the purposes of sporting communities, a few cursory remarks are called for. First of all, Durkheim's "collective representations" as factors of we-ness are obviously a fair starting point, but the Lynds $(1929,402-03)$ and other social thinkers have demonstrated that shared collective identities are not about the values purportedly articulated and propagated in a specific sports environment. Rather, they are about the belief entertained by participants that they form a "we" because of these values. Consciously or not, players or fans engage in the fiction of their belonging to a uniting "we," usually to foster a better version of their self.

Second, it does not follow that this fictitious sense of community is without effect. Corbin (1997) and Saunier (1996) have shown that beliefs about one group's so-called identity, however imagined or assigned by outsiders, are internalized and translated into tangible facts. These include educational choices, voting patterns, or even public policies. Most recently, controversies about sports club owners who threaten municipal authorities with relocating if they fail to provide taxpayers' money for the maintenance or construction of their sporting arenas, illustrate that believing in the town-and-team narrative is often unrequited. In the language of religion, so often misused in sport studies, the officiant does not in fact form one flesh with the communiant. A perfect example of the inability of sports fans to keep "their" beloved team in "their" city 
occurred in 1957 when Brooklyn Dodgers' owner Walter O'Malley left the overcrowded district of Flatbush to the spacious promises of Los Angeles' car-and-TV economy, breaking the hearts of thousands of faithful fans (Sullivan, 1987; Marquis, 2009).

In closing, I would like to ask a candid question: what for do people get so excited and exuberant about sports? Since a good share of sport fans hold college degrees, the dubious explanation that sport crowds are mindless and brutish must be ruled out. A more seductive answer comes from esthetics scholar Hans Gumbrecht (2006, quoted 221) who sees infatuation with sports as a reflection of mankind's hunger for beauty and the transcendental harmony of minds and bodies. However flattering, this cannot account for whole groups of people creating permanent communities through sports. of course, participation in sports spectatorship may provide communitas, as Victor Turner (1967) called the temporary abolition of structure in relationships usually segregated by class, race, gender, or hierarchy. Yet, transcending day-to-day joy and misfortunes is admittedly a common denominator to all voluntary associations. Don't sports communities differ from, say, a mahjong club or a faith-based congregation? I would hypothesize that sport has an idiosyncratic way of making communities. First, its physicality, either lived or experienced by proxy, sets the imagination in motion to conjure up images of one's body employed in a non-utilitarian, yet vital fashion. Second, unlike all other recreational pastimes, sport is unscripted: the outcome remains unknown and unpredictable until the final whistle sounds. However, unchanging rules, ritualized settings, and recurrent mini-dramas provide delightful returns of the same which reinforce the fans' faith in the fiction of their belonging.

\section{BIBLIOGRAPHY}

ANDERSON, Benedict, Imagined Communities: Reflections on the Origin and Spread of Nationalism, London, Verso, 1991.

BENDER, Thomas, Community and Social Change, Baltimore, Johns Hopkins University Press, 1982.

COAKLEY, Jay, “Master Bibliography For Sports In Society, 1994-2009," unpublished manuscript. COONTZ, Stephanie, The Way We Never Were: American Families and the Nostalgia Trap, New York, Basic Books, 1992.

CORBIN, Alain, "Du Limousin aux cultures sensibles" in RIOUX and SIRINELLI, eds., Pour une histoire culturelle, Paris, Seuil, 1997.

DYRESON, Mark, “Maybe It's Better to Bowl Alone: Sport, Community and Democracy in American Thought" in NASSH Proceedings, 1997.

FOLEY, Michael and Bob EDWARDS, "The Paradox of Civil Society", in Journal of Democracy, 1996, vol. 7, n³, 38-52.

GUMBRECHT, Hans Ulrich, In Praise of Athletic Beauty, Cambridge, Mass., Belknap Press of Harvard University Press, 2006. 
HARDY, Stephen, How Boston Played: Sport, Recreation, and Community, 1865-1915, Boston, Northeastern University Press, 1982.

HARRIGAN, Patrick, The Detroit Tigers: Club and Community, 1945-1995, Toronto, University of Toronto Press, 1997.

HILL, Jeff and Jack WILLIAMS, Sport and Identity in the North of England, Keele, Staffordshire, Keele University Press, 1996.

HOLT, Richard, "Working Class Football and the City: the Problem of Continuity" in British Journal of Sport History, 1986, vol. 3, 5-17.

JOSEPH, Miranda, Against the Romance of Community, Minneapolis, University of Minnesota Press, 2002.

LEMANN, Nicholas, "Kicking in Groups” in The Atlantic Monthly, April 1996.

LESTRELIN, Ludovic, L'Autre public des matchs de football. Sociologie des supporters à distance de l'Olympique de Marseille, Paris, Éditions de l'École des hautes études en sciences sociales, 2010.

LYND, Robert Staughton and Helen Merrell LYND, Middletown, a Study in Contemporary American Culture, New York, Harcourt, Brace and Company, 1929.

MARQUIS, Peter, “Brooklyn et 'ses' Dodgers. Baseball et construction des identités urbaines aux Etats-Unis (1883-1957)", thèse de doctorat en histoire et civilisation, École des hautes études en sciences sociales, Paris, 2009.

PROCTER, David E., Civic Communion: The Rhetoric of Community Building, Rowman \& Littlefield, 2005.

PUTNAM, Robert D., "Bowling Alone: America's Declining Social Capital” in Journal of Democracy, January 1995, vol. 6, n¹, 65-78.

RADER, Benjamin G., "The Quest for Subcommunities and the Rise of American Sport" in American Quarterly, 1977, vol. 29-4, 355-69.

SAUNIER, Pierre-Yves, "Représentations sociales de l'espace et histoire urbaine: les quartiers d'une grande ville française, Lyon au XIXè siècle" in Histoire sociale/Social history, 1996, vol. 57, 23-52.

SULLIVAN, Neil J., The Dodgers Move West, New York, Oxford University Press, 1987.

TURNER, Victor, The Forest of Symbols: Aspects of Ndembu Ritual, Ithaca (N.Y.), Cornell University Press, 1967.

WILCOX, Ralph et al., eds., Sporting Dystopias. The Making and Meaning of Urban Sport Cultures, Albany, State University of New York Press, 2003.

\section{NOTES}

1. A few exceptions are Dyreson (1997), Harrigan (1997), Hill \& Williams (1996), and Wilcox et al. (2003). Yet, a search through Coakley's 120-page long bibliography on sports and society (2009) retrieves only 3 titles with the word "community."

2. The "Curse of the Bambino" refers to that fact that since 1919 when Babe Ruth, also called "Il Bambino," was sold to the Yankees, the Red Sox had continuously lost to them in championship games, often with much flair. The curse was broken in 2004, 2007 and 2013. 
INDEX

Subjects: Recensions

\section{AUTHORS}

PETER MARQUIS

Rouen University 